\title{
Peh Production, Flagellum Synthesis, and Virulence Reduced in Erwinia carotovora subsp. carotovora by Mutation in a Homologue of cytR
}

\author{
Hiroyuki Matsumoto, Hironobu Muroi, Masahiro Umehara, Yoshimasa Yoshitake, and Shinji Tsuyumu \\ Faculty of Agriculture, Shizuoka University, 836 Ohya, Shizuoka 422-8529, Japan \\ Submitted 7 October 2002. Accepted 2 January 2003.
}

\begin{abstract}
Erwinia carotovora subsp. carotovora is a causal agent of soft-rot diseases in a wide variety of plants. Here, we have isolated a new regulatory factor involved in the virulence of E. carotovora subsp. carotovora by in vivo insertional mutagenesis using a transposon Tn5. The gene was homologous to cytR encoding a transcriptional repressor of nucleoside uptake and catabolism genes in Escherichia coli, Salmonella typhimurium, and Vibrio cholerae. Phenotypic characterization of a nonpolar deletion mutant of the $c y t R$ homologue $(\Delta c y t R)$ revealed that the $\Delta c y t R$ mutant produced a reduced level of polygalacturonase (Peh) and lost its motility compared to that in the parental strain. With electron microscopy, the $\Delta c y t R$ mutant was shown to be aflagellate. Furthermore, the expression of fliA and fliC (encoding $\sigma^{28}$ and flagellin, respectively) was also reduced in $\Delta c y t R$ mutant. The virulence of $\Delta c y t R$ mutant was reduced in Chinese cabbage and potato compared to that of the parental strain. These results suggest that the CytR homologue of $E$. carotovora subsp. carotovora positively controls Peh production and flagellum synthesis and plays an important role in its pathogenicity.
\end{abstract}

Soft-rot Erwinia spp., including Erwinia carotovora subsp. carotovora, is widely distributed in the world and causes serious damage on a wide variety of plants (Perombelon and Kelman 1980). The main factors responsible for its pathogenicity are thought to be cell-wall-degrading enzymes (Kotoujansky 1987; Barras et al. 1994) such as pectate lyase (Pel), polygalacturonase $(\mathrm{Peh})$, cellulase $(\mathrm{Cel})$, and protease (Prt). These enzymes are produced and secreted into the external milieu in large quantity. Among these enzymes, Collmer and Keen (1986) noted that Pel and Peh play a crucial role in the pathogenicity of soft-rot Erwinia spp. because Escherichia coli clones that produce Pel or Peh macerate potato tuber tissues. Consequently, a number of regulatory factors that control these enzymes have been identified in soft-rot Erwinia spp. (Barras et al. 1994; Hugouvieux-Cotte-Pattat et al. 1996; RobertBaudouy et al. 2001). Nevertheless, in planta colonization by soft-rot Erwinia spp. is a multifunctional process that requires numerous secondary factors such as exopolysaccharides (EPS) (Condemine et al. 1999), lipopolysaccharide (LPS) (Schoonejans et al. 1987), iron assimilation (Enard et al. 1988), the Hrp system (Bauer et al. 1994), motility (Mulholland et al. 1993), and proteins involved in resistance against plant defense mechanisms (Lopez-Solanilla et al. 1998; Hassouni et al.

Corresponding author: S. Tsuyumu; E-mail: tsuyumu@agr.shizuoka.ac.jp; Telephone and Fax: +81-54-238-4823
1999). However, few of these regulatory factors have been reported to date.

In animal pathogenic bacteria such as E. coli and Salmonella spp., the bacterial flagellum that directs the bestunderstood mode of motility is an important factor for hostparasite interaction (Ottemann and Miller 1997; Josenhans and Suerbaum 2002). The structure consists of a long helical filament (composed of a single protein called flagellin) anchored in the cell envelope by a flexible hook and basal body complex (Aizawa 2000). Interestingly, the components of the flagellar export apparatus are evolutionarily related to the type III secretion system (Aizawa 2001) that is used for the transport of virulence proteins into eukaryotic host cells (Hueck 1998). Now we know that the flagellum itself functions in secreting certain virulence factors (Young et al. 1999). Assembly of the flagellar components proceeds from cell-proximal to cell-distal structures, that is, it begins with the basal body, proceeds with the hook, and is completed with the filament. The development of flagellar assembly or motility is responsive to various environmental conditions and closely associated with the regulation of known virulence factors (Ottemann and Miller 1997; Josenhans and Suerbaum 2002).

More than 50 genes are known to be involved in flagellar formation and function in E. coli and Salmonella spp. (Chilcott and Hughes 2000). The transcription of these genes is organized in a three-tier hierarchy (early, middle, and late) and is coordered with the hierarchy for flagellar assembly (Chilcott and Hughes 2000; Aldridge and Hughes 2002).

In plant pathogenic bacteria such as Agrobacterium tumefaciens (Chesnokova et al. 1997), Ralstonia solanacearum (Tans-Kersten et al. 2001), and E. carotovora subsp. atroseptica (Mulholland et al. 1993), the motility, flagellum, or both contribute to their invasive virulence. In addition, Pirhonen and associates (1991) have shown that many nonmotile mutants of E. carotovora subsp. carotovora, produced by transposon mutagenesis, had reduced virulence on tobacco seedlings. The gene responsible for this phenotype has not been identified yet. So far, in soft-rot Erwinia spp., RsmA (E. carotovora subsp. carotovora), HexA (E. carotovora subsp. carotovora and E. carotovora subsp. atroseptica)/PecT (E. chrysanthemi), HexY (E. carotovora subsp. carotovora and E. carotovora subsp. atroseptica), and H-NS (E. chrysanthemi) are known to control the expression of another virulence determinant—motility-as well as to control one or more wall-degrading enzymes (Mukherjee et al. 1996; Castillo and Reverchon 1997; Harris et al. 1998; Shih et al. 1999; Nasser et al. 2001).

To gain further insight into the pathogenicity of E. carotovora subsp. carotovora, we looked for new regulatory factors 
involved in virulence without limiting our assays to the regulatory factors for Pel and Peh. Here we provide data that one of the factors, a homologue of CytR, which represses nucleoside uptake and catabolism in nucleoside-poor environments in $E$. coli (Valentin-Hansen et al. 1996), is an important virulence factor in E. carotovora subsp. carotovora.

\section{RESULTS}

Isolation of avirulent mutants

in E. carotovora subsp. carotovora.

By Tn5 mutagenesis in E. carotovora subsp. carotovora EC1-N, a number of mutants with reduced virulence on Chi-

1 GICGACCCCACGGACGGTTAGCGTTICCTGITAGCTAAGTITGAGTTTCTTGCCATGCATTTTTTGCGAGCGCCGTCGAGAACACGACAT $\begin{array}{lllllllllll}V & D & P & T & D & G & *\end{array}$ Sah

CytR-box 1 CRP-box

91 TCATCACACTICCTGTGCAAATTAAGCAACAAAACCTGCGTGCAATCTGTTATCACTGTTTGCGCAGGCAGTATGCTGAGGCCTGGTCGT CytR-box 2 $-35$ $-10$

181 GTAGTGATGAATCGIGCCACTCAGTCGGCATACCGCGCCGAAAAGCATTACCCGTAATCATAGAAAGTCAGTAGACAGOGGCGTTCTGCT

271 GACAGICAGOGCCAGTTAACGCIGACGCAAGGAGAAAAGCGTTGAAGCAGAAGAAAGGCGTCACCACGGCGACGATGAAAGACGIGGCGG SD

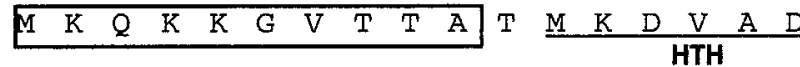

361 ATGAGCCGGGCGITTCCACCGOGACCGTATCCCGAACGITAATGAACCCAGAGAAAGICTCTGCGACCACCCGCAGGAAGGTCGAGCAGG $\begin{array}{lllllllllllllllllllllllllllllll}E & A & G & V & S & T & A & T & V & S & R & T & L & M & N & P & E & K & V & S & A & T & T & R & R & K & V & E & Q & A\end{array}$

451 CTGTCATCGCCGITGGCTATTCGCCCCACGCGCTCAACAGGAATCTCAAGCGTAACGAATCGCGTACGATCCIGACGATCGTCCCAGATA $\begin{array}{llllllllllllllllllllllllllllll}V & I & A & V & G & Y & S & P & H & A & L & N & R & N & L & K & R & N & E & S & R & T & I & I & T & I & V & P & D & I\end{array}$

541 TCIGCGATCCCTATTTCTCCGAAATATTTCGCGGGATCGAGGAAACGGCAGCCGAACACGGCTAICTGGIGTIGATTIGGCGATIGCGCIC

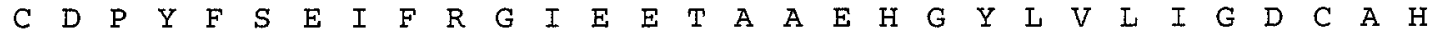

631 ACCAACATCAAAAAGAAAAACCTICGTCGACCTGATTATTACCAAGCAGATCGATGGAATGCIGTTACTCGGITCCAACCIACCGITIG $\begin{array}{llllllllllllllllllllllllllllllll}Q & H & Q & K & E & K & T & F & V & D & L & I & I & T & K & Q & I & D & G & M & L & L & L & G & S & N & L & P & F & D\end{array}$ San

721 ACGCAGGCCAGGAAGAGCAGCGTAATCTGCCGCCGATGGTGATGGCCAATGAGTTCICACCGGATCTGGCGCTGCCAACCGIGCATATCG $\begin{array}{llllllllllllllllllllllllllllllll}A & G & Q & E & E & Q & R & N & L & P & P & M & V & M & A & N & E & F & S & P & D & L & A & L & P & T & V & H & I & D\end{array}$

811 ATAACCTGACCGCCGCCTTTGAAGCCGTACATTATCTGTATCAGGCGGGTCATCAGCGTATTGCCTGCATTGCCGGCCCGGAGCACATGC

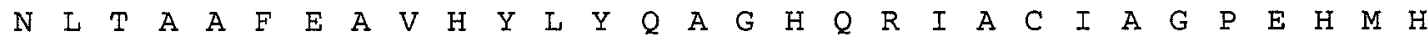

901 ATCTGAGCCAATATCGITIGCAGGGGTACATTCAGGCTTTGCGCCGCAACGGGATTCTGATCGATAACCAGTACATCTTTCGGGGTGATT

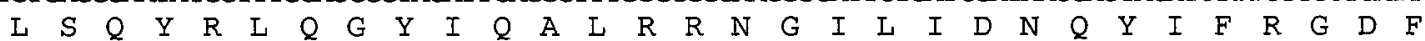

991 TCACCTATGAAACCGGGATTAACGGCCTGATTGCGCTAATGCAGCATCCGCAGCCGCCCAGCGCGATCITCTGTCACAGCGACCTCATGG $\begin{array}{lllllllllllllllllllllllllllllll}T & Y & E & T & G & I & N & G & L & I & A & L & M & Q & H & P & Q & P & P & S & A & I & F & C & H & S & D & L & M & A\end{array}$

1081 CACIGGGCGIGCTGGCGCAGGCCAGAAAGATGGGGCIGGACATCCCACGCGATCTCICCATTATTGGITTCGATGATATCGAACAGGCGC

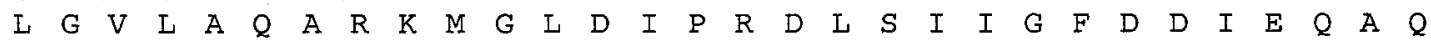

1171 AATACAGTTGGCCICCGCTGACGICTGTCGCCCAGCCCCGITAICAGATCGGACGTGAGGCAATGCTGCTACICITAGAGCAGTTGCAAG

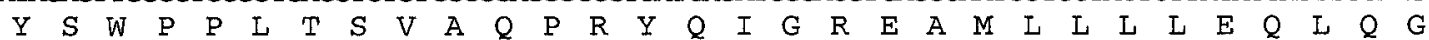

1261 GTAACACGGTACAAAGCGGTTCCCGCCTATTGTCCAGTGAGCIGGTCATACGCGACAGCGIOGCCGCGCCGAATIACGCCCGTAACAGGC $\begin{array}{lllllllllllllllllllllllllllllllll}N & T & V & Q & S & G & S & R & L & L & S & S & E & L & V & I & R & D & S & V & A & A & P & N & Y & A & R & N & R & L\end{array}$

1351 TTIAAGACTICAGGIGCTGGTCAAATATTIGAGGGTTCAGTAACATGACCCCCTAATTATATTATTMATCTATCAATTCACAGCGAAACG *

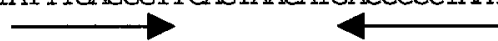

1441 ACAGTGGCACAAAGAGACTACGTGAGCCGGGGACGTTCATCAGGAACGCGCCGGAAAACGACAAATAGCCGAAAAAAAGGCAAGGCTTCA $\begin{array}{llllllllllllllllllllllllllllllllll}M & A & Q & R & D & Y & V & S & R & G & R & S & S & G & T & R & R & K & T & T & N & S & R & K & K & G & K & A & S\end{array}$

1531 GGTGCATCCAAAACGATGATC $\begin{array}{lllllllllllll}G & A & S & K & T & M & I\end{array}$

1551

\section{SauBAI}

Fig. 1. Nucleotide and deduced amino acid sequences of the $c y t R$ homologue of Erwinia carotovora subsp. carotovora EC1. Translational start site and stop site are shown at positions 312 to $314 \mathrm{nt}$ and 1,353 to $1,355 \mathrm{nt}$, respectively. First 10 amino acid residues sequenced from the over-expressed protein are shown in a box. Putative -35 and -10 regions of $\sigma^{70}$ promoter, a ribosome-binding site, and a HTH motif are underlined. In front of the putative promoter region, one potential cyclic AMP receptor protein-binding site and two potential CytR (CytR homologue)-binding sites are shown by a pair of underlines. An imperfect inverted repeat is shown by inverted arrows. Portion of amino acid sequences of PriA and FtsN homologues are also shown. 
nese cabbage were isolated (data not shown). Several mutants such as YMU1, YMU5, and YMU18 were nonmotile on semisolid agar plates. The sequence of the Tn5-inserted region of YMU1 and YMU5 was homologous to transcriptional regulatory genes, $f l h C$ and $f l h D$, respectively (Matsumoto et al., In press), which are involved in the initiation of the expression of flagellum-related genes in many gram-negative bacteria such as E. coli and Salmonella spp. (Kutsukake et al. 1990; Liu and Matsumura 1994). On the other hand, YMU18 had double insertions of Tn 5 on its chromosome, and the sequences of the Tn5-inserted regions were homologous to $c y t R$ (required for nucleoside uptake and catabolism: Valentin-Hansen et al. 1996) and mutS (required for DNA mismatch repair: Modrich and Lahue 1996) genes in bacteria such as E. coli.

\section{Cloning and sequencing of the cytR homologue of E. carotovora subsp. carotovora.}

From a genomic library of E. carotovora subsp. carotovora EC1, a clone that contained the $c y t R$ homologue was obtained using the BamHI fragment of Tn5 flanking the $3^{\prime}$ region of the $c y t R$ homologue (from the chromosome of YMU18) as the probe. The putative open reading frame (ORF) of the cytR homologue of E. carotovora subsp. carotovora EC1 was predicted to encode a protein of 347 amino acid residues with a calculated molecular mass of $38.6 \mathrm{kDa}$ (Fig. 1). The molecular mass agreed with the value of $40 \mathrm{kDa}$ determined from sodium dodecyl sulfate-polyacrylamide gel electrophoresis (SDSPAGE) profile of the over-expressed protein (data not shown). The N-terminal amino acid sequence of the over-expressed protein completely matched that of the putative ORF. Accordingly, the initiation codon for this ORF was the rare uraciluracil-quanine (UUG). The CytR homologue of E. carotovora subsp. carotovora $\mathrm{EC} 1$ had 71.7, 70.2, and 63.0\% amino acid identities to those of E. coli K-12 (Valentin-Hansen et al. 1986), Salmonella typhimurium KP1001 (Thomsen et al. 1999), and Vibrio cholerae O1 EI Tor (Haugo and Watnick 2002), respectively. Southern blot analyses for EcoRI- or BamHI-digests of the total DNAs from various bacteria using the $c y t R$ homologue of E. carotovora subsp. carotovora EC1 as the probe showed the signals in E. coli, Salmonella and Erwinia species but not in other bacteria in genera such as Ralstonia, Pseudomonas, Xanthomonas, and Agrobacterium under high stringency hybridizing conditions (data not shown). These data indicated that the cytR homologue was highly conserved among enteric bacteria. A potential helix-turn-helix (HTH) DNA-binding motif can be found at amino acids 12 to 31 of the CytR homologue of E. carotovora subsp. carotovora EC1 (Fig. 1).

Purine-rich AGGA found nine nt upstream may be considered as a putative Shine-Dalgarno (SD) sequence (Fig. 1). A possible $\sigma^{70}$ promoter region can be found at 140 to $145 \mathrm{nt}$ ($35)$ and 162 to $167 \mathrm{nt}(-10)$. The cytR of E. coli had been reported to be self-regulated by the products complexed with cyclic AMP receptor protein (CRP) (Pedersen et al. 1992). One potential CRP-binding site (Gunasekera et al. 1992) centered at $90.5 \mathrm{nt}$ (83 to $87 \mathrm{nt}$ and 94 to $98 \mathrm{nt}$ ) and two potential CytR (CytR homologue) binding sites (Rasmussen et al. 1993) centered at $62 \mathrm{nt}$ and $112 \mathrm{nt}$ (56 to $60 \mathrm{nt}$ and 64 to $68 \mathrm{nt}, 106$ to $110 \mathrm{nt}$ and 114 to $118 \mathrm{nt}$ ) were found in front of the putative promoter region. A 10-bp imperfect inverted repeat (with a spacer sequence of $11 \mathrm{bp}$ ) followed by an adenine-thymine (AT)-rich sequence was found downstream of the ORF $(1,377$ to $1,407 \mathrm{nt}$ ) and may function as a $\rho$-independent transcriptional terminator.

Within the fragments shown, a portion of the amino acid sequences of the PriA homologue for a replication fork restart (Nurse et al. 1990) and the FtsN homologue for cell division
(Dai et al. 1993) were found before and after the cytR homologue, respectively (Fig. 1). The order of these genes in the vicinity of the cytR homologue of E. carotovora subsp. carotovora $\mathrm{EC} 1$ is strikingly similar to those of E. coli, $S$. typhimurium, and V. chorelae.

\section{Construction}

of a nonpolar deletion mutant of the cytR homologue.

Although a $\rho$-independent transcriptional terminator-like sequence is located downstream of the $c y t R$ homologue, a putative start codon of the fts $N$ homologue is located in the immediate 89-bp downstream from the stop codon of the $c y t R$ homologue in E. carotovora subsp. carotovora EC1 (Fig. 1). In fact, using reverse transcription-polymerase chain reaction (RT-PCR) with the primers located in the ORF of the $c y t R$ homologue and of the fts $N$ homologue, we found mRNA extending between them (data not shown). Therefore, the $c y t R$ and fts $N$ homologue genes in E. carotovora subsp. carotovora EC1 may be transcribed as a single mRNA.

To define precisely the phenotype of the cytR homologue, a nonpolar deletion mutant of the $c y t R$ homologue (denoted as $\Delta c y t R$ ) in the frame corresponding to amino acids 110 to 220 was constructed in E. carotovora subsp. carotovora EC1-N by double homologous recombination (Horton et al. 1990; Kaniga et al. 1991; Lefebvre et al. 1995). The deletion of the cytR homologue on its chromosome was confirmed by PCR analysis using primers cytR-BF and cytR-HR (data not shown). Growth, determined by $\mathrm{OD}_{660}$, of the $\Delta c y t R$ mutant was slightly delayed compared to that of the parental strain (EC1$\mathrm{N}$ ) in yeast extract-peptone (YP) medium (Fig. 2). However, the number of cells in the $\Delta c y t R$ mutant was 1.6 times higher than that in the parental strain at the early stationary phase $\left(\mathrm{OD}_{660}=1.0\right)$ (data not shown). By light microscopic observation, the cells of the $\Delta c y t R$ mutant were smaller than that of the parental strain. These results indicated that the cell division might be affected in the $\Delta c y t R$ mutant.

\section{Loss of motility in $\Delta c y t R$ mutant.}

Growth on semisolid agar plate revealed that the $\Delta c y t R$ mutant was nonmotile as was YMU5 (EC1-N flhD::Tn5), while the parental strain (EC1-N) was motile (Fig. 3A). Light microscopy also confirmed that the $\Delta c y t R$ mutant grown to late exponential early stationary phase $\left(\mathrm{OD}_{660}=\right.$ approximately $0.8 \sim 1.0$ ) in YP medium was nonmotile, while the parental strain was motile (data not shown). Thus, the homologue of

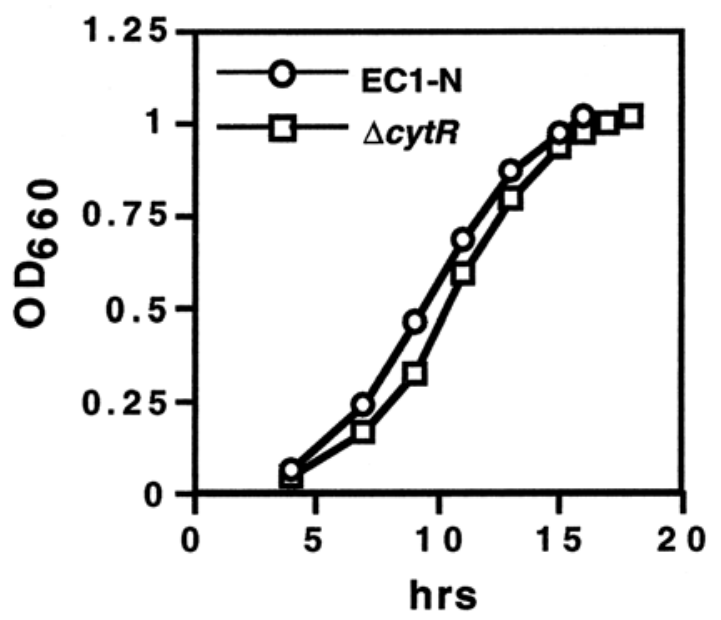

Fig. 2. Growth of EC1-N and $\Delta c y t R$ mutant. Optical density of the suspensions of cells grown in YP medium at $27^{\circ} \mathrm{C}$ was measured periodically using a spectrophotometer at $660 \mathrm{~nm}$. 
CytR in E. carotovora subsp. carotovora EC1 may control the synthesis, assembly, or operation of the flagellum. Another strain of E. carotovora subsp. carotovora also lost its motility on semisolid agar plate as a result of a mutation constructed in the same homologue of $c y t R$ (data not shown).

Negative staining with electron microscopy demonstrated the lack of flagellum in the $\Delta c y t R$ mutant, while a number of peritrichous flagella were observed in the parental strain (Fig. 3B). Because not even a flagellar hook or basal body was observed in the $\Delta c y t R$ mutant after treatment with osmotic pressure, the loss of motility in the $\Delta c y t R$ mutant seemed to result from either the absence of flagellum synthesis or the lack of assembly of its components as opposed to an inability to use the flagellum (a motor-deficient phenotype). As indicated with a growth study of $\Delta c y t R$, the size and the shape of cells also seemed to be affected. The $\Delta c y t R$ mutant formed small, asymmetrical, rectangular cells as in YMU5, while the parental strain formed large, symmetrical, rectangular cells. This asymmetry may be caused by the expression or modulation of $f l h D / F l h D$ because $f l h D$ in $E$. coli also has been reported to affect cell division (Pruss and Matsumura 1996).

\section{The CytR homologue controls the expression} of genes required for flagellum synthesis.

As a representative gene of each class of flagellar regulon, expression of $f l h D$ (early: a master regulator primarily for expression of middle and some late genes), fliA (middle: a flagellum-specific sigma factor, $\sigma^{28}$, primarily for late gene expression), and $f l i C$ (late: a flagellar component called flagellin) was analyzed through RT-PCR. Although the expression of $f l h D$ in $\Delta c y t R$ mutant slightly increased over that in the parental strain (EC1-N), the expression of fliA and fliC was reduced in the $\Delta c y t R$ mutant as it was in YMU5 (Fig. 4). These results suggested that the CytR homologue in E. carotovora subsp. carotovora might positively control the expression of fliA and fliC.

\section{Production of extracellular enzymes in $\Delta c y t R$ mutant.}

When the activity of extracellular enzymes was compared by plate assays, the size of haloes formed by $\Delta c y t R$ in Pel-, Cel-, and Prt-plates was slightly larger than those in the parental strain $(\mathrm{EC} 1-\mathrm{N})$ in both extracellular and total fractions and in both noninducing and inducing conditions (Fig. 5A). The activity of Peh, however, was drastically reduced in the $\Delta c y t R \mathrm{mu}-$ tant compared to that in the parental strain in both extracellular and total fractions and in both noninducing and inducing conditions. Thus, the cytR homologue of E. carotovora subsp. carotovora EC1 may positively control the production of Peh.
Spectrophotomeric assays of Pel, and Peh gave similar results to those in plate assays (Fig. 5B).

\section{Reduced-virulence in $\Delta c y t R$ mutant.}

After the inoculation in Chinese cabbage (Fig. 6) and potato (data not shown) virulence of the $\Delta c y t R$ mutant was confirmed to be greatly reduced compared to that of the parental strain (EC1-N). The $\Delta c y t R$ mutant macerated only around the inoculation sites on both hosts $24 \mathrm{~h}$ after the inoculation, while the parental strain macerated them extensively. Because YMU5 (EC1-N flhD::Tn5) but not the peh-deficient mutant MH322 (EC1-N peh::Tn3-gus) also had reduced virulence in Chinese cabbage and potato, the reduced virulence of $\Delta c y t R$ mutant may result at least partly from the absence of flagellar formation leading to a loss of motility. The symptoms by both the $\Delta c y t R$ mutant and YMU5 did not enlarge even five days after the inoculations.

\section{DISCUSSION}

Here, Peh production, flagellum synthesis, and virulence were severly reduced in the $\Delta c y t R$ mutant. However, the phenotypes, including the virulence in $\Delta c y t R$, were not restored by introducting the $c y t R$ homologue of E. carotovora subsp. carotovora EC1 on a low-copy-number vector, pRK415 (Keen et al. 1988) (data not shown). Various constructs such as the transcriptional fusion of the $c y t R$ homologue to lac promoter using pRK415 did not complement these phenotypes. However, all mutants obtained by the double homologous recombination in the cytR homologue in E. carotovora subsp. carotovora EC1-N had the same phenotypes. In addition, another strain of E. carotovora subsp. carotovora had a similar phenotype from a mutation in the same homologue of $c y t R$ (data not shown). Similarly, in E. carotovora subsp. carotovora, the complementation for the production and secretion of extracellular enzymes in the mutant of the expM gene was not restored by the introduction of a plasmid carrying the expM, though virulence was restored (Andersson et al. 1999). The expM gene encodes a twocomponent response regulator that negatively regulates the stability of the sigma factor RpoS $\left(\sigma^{s}\right)$ at the protein level. In a system involving such a complex regulatory network, complementing the phenotype in these regulatory mutants may be difficult.

In the pathogen of bacterial wilt disease $R$. solanacearum, Peh production, motility, and virulence have been reported as positively controlled by a two-component regulator, PehSR (Allen et al. 1997). The transcription of pehSR has been shown to be negatively controlled by a cell density-responsive global regulator, PhcA, which positively controls other virulence fac-

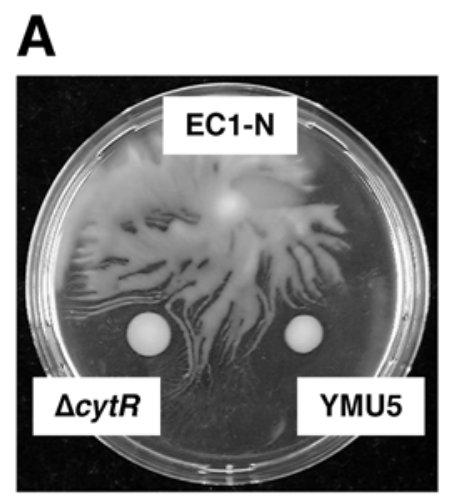

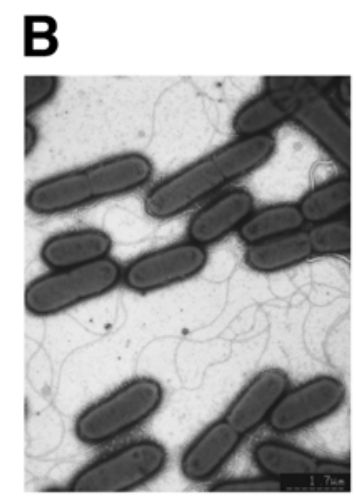

EC1-N

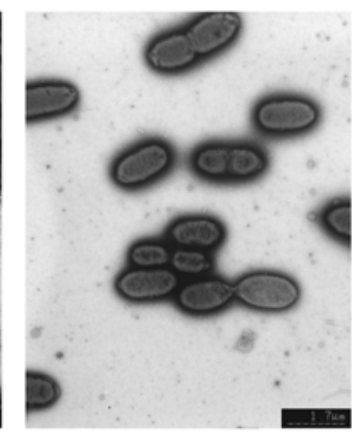

$\Delta$ cytR

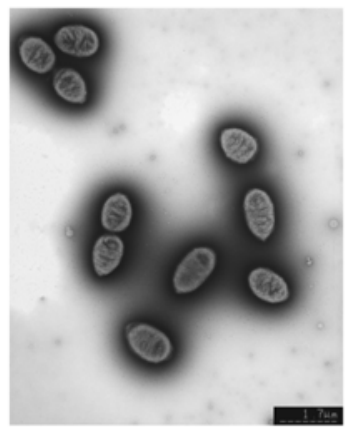

YMU5

Fig. 3. Motility assay and electron microscopy of EC1-N, $\Delta c y t R$ mutant, and YMU5. A, Motility on a semisolid agar plate after $48 \mathrm{~h}$. B, Cells grown to early stationary phase $\left(\mathrm{OD}_{660}=\right.$ approximately 1.0$)$ in YP medium at $27^{\circ} \mathrm{C}$. Two independent experiments gave similar results. 
tors such as extracellular polysaccharides (EPS) and endoglucanase (Brumbley and Denny 1990; Allen et al. 1997). With such a complex regulatory system, the CytR homologue in $E$. carotovora subsp. carotovora may simultaneously control Peh production, motility, and virulence.

CytR was first reported as an important virulence factor in the human intestinal pathogen $V$. cholerae (Haugo and Watnick 2002). CytR in V. cholerae negatively controls development of its biofilm through the repression of vps genes, which encode enzymes required for the synthesis of EPS of $V$. cholerae. However motility in $V$. cholerae was not affected by the deletion of $c y t R$. Motility and EPS production are generally coregulated in the cases of plant-associated bacteria such as $R$. solanacearum, Sinorhizobium meliloti, and E. chrysanthemi (Brumbley and Denny 1990; Wei and Bauer 1999; Nasser et al. 2001). Accordingly, the downstream regions of the CytR/CytR homologue regulatory network may be distinguishable between $V$. cholerae and E. carotovora subsp. carotovora.

In $E$. coli, the genes that belong to the CytR regulon (deo$C A B D, t s x, c d d, u d p, c y t R$, and nupG) encode transport proteins and enzymes required for nucleoside uptake and catabolism (Hammer-Jespersen 1983; Valentin-Hansen et al. 1996). In addition, CytR negatively regulates the transcription of two additional genes, ppiA (Norregaard-Madsen et al. 1994) and rpoH (Kallipolitis and Valentin-Hansen 1998), which are related to protein folding. Perhaps the CytR homologue in E. carotovora subsp. carotovora controls Peh production, flagellum synthesis, or both via one or more controls of these genes.

The similarity of cell morphology between the $\Delta c y t R$ mutant and YMU5 (Fig. 3B) suggests that the absence of flagellar formation in the $\Delta c y t R$ mutant results from an effect on the expression or modulation of $f l h D / F l h D$. However, the expression of $f l h D$ in the $\Delta c y t R$ mutant was similar, though slightly higher, to that in the parental strain (Fig. 4). Accordingly, the absence of flagellar formation in $\Delta c y t R$ mutant did not seem to result from an effect on the regulation of $f l h D$ at the transcriptional level. In previous work, mutations in $d n a K$, dnaJ, or grpE in $E$. coli and $c l p X P$ in $S$. enterica serovar Typhimurium have been shown to become aflagellate and hyperflagellate, respectively (Shi et al. 1992; Tomoyasu et al. 2002). These genes encode molecular chaperones (DnaK, DnaJ, GrpE) and an ATPdependent protease $(\mathrm{ClpXP})$ that are involved in protein folding, repair, and degradation under normal and stress conditions. The abnormal flagellar formation in these mutants is explained together with the effect on expression or modulation of the flhDC (flhD and $f l h C$ in a single operon)/FlhDC (heteromultimer) master regulator. Particulary in the latter case (hyperflagellate phenotype in $\operatorname{clpXP}$ mutant), $f l h D C / \mathrm{FlhDC}$ is modu-

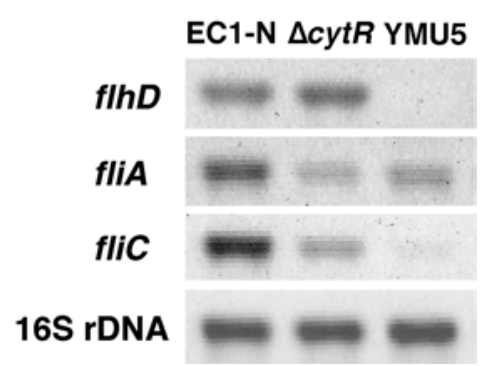

Fig. 4. Reverse transcription-polymerase chain reaction (RT-PCR) analysis of levels of expression of flagellum-related genes. Bacterial cells were grown to late exponential phase $\left(\mathrm{OD}_{660}=\right.$ approximately 0.7$)$ in YP medium at $27^{\circ} \mathrm{C}$ and then RNA was extracted. One $\mu \mathrm{g}$ of total RNA was used as the template. Photographs are results of $25(\mathrm{flhD}, \mathrm{fliC}$, and $16 \mathrm{~S}$ rDNA) or 33 (fliA) cycles in PCR (in which all products tested had linear ranges of detection) following their RT-reactions. Three independent experiments had similar results.
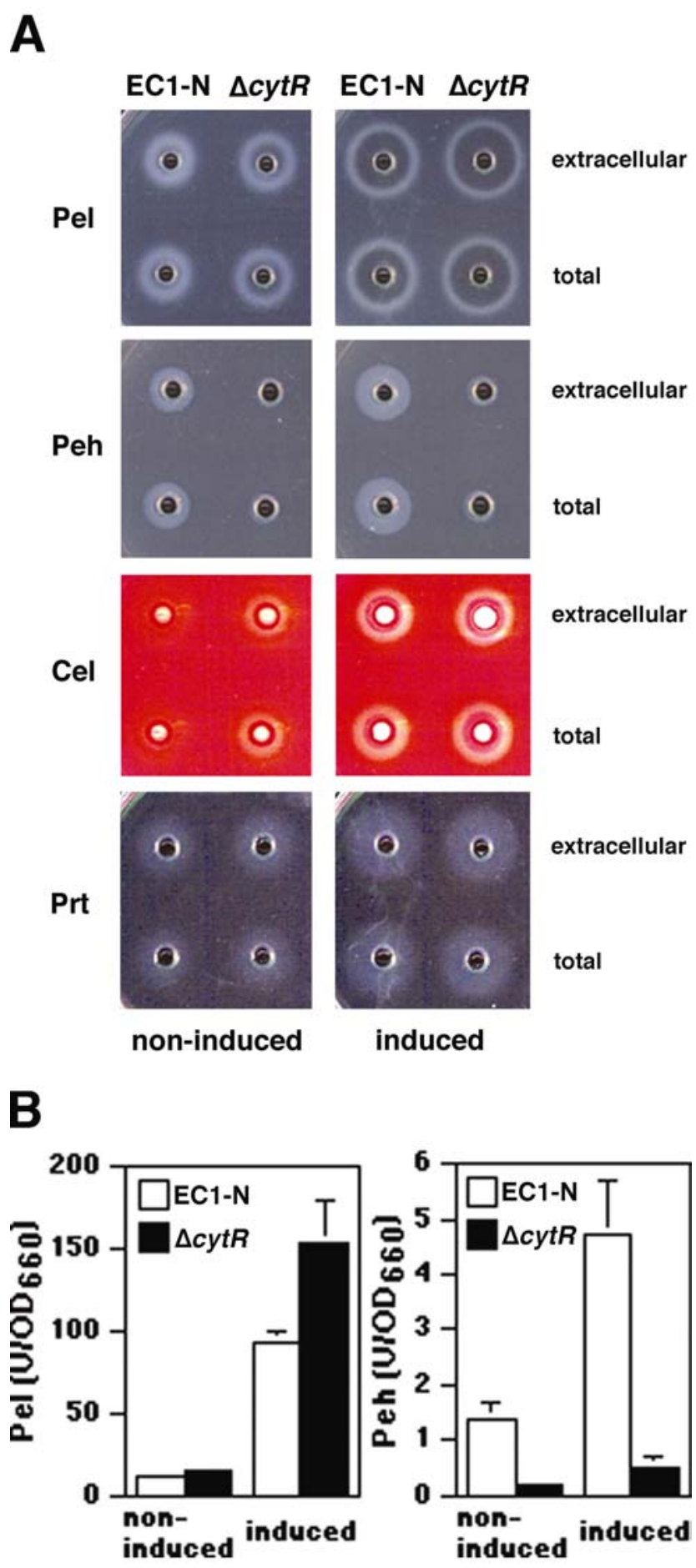

Fig. 5. Production of extracellular enzymes in EC1-N and $\Delta c y t R$ mutant. Bacterial cells were grown until early stationary phase at $27^{\circ} \mathrm{C}$ in $\mathrm{YP}$ medium (noninduced) or YP medium containing PGA (induced). A, Plate assays for the activity of pectate lyase (Pel), polygalacturonase (Peh), cellulase (Cel), and protease (Prt). After adjustment of the optical density of cell suspensions at $660 \mathrm{~nm}$ to 1.0 by adding sterilized distilled water, $30 \mu \mathrm{l}$ of the culture supernatants (for extracellular activity) or of the supernatants of the sonicated-cell extracts (for total activity) were applied to each well. After incubation at $27^{\circ} \mathrm{C}$, each plate was treated as described in MATERIALS AND METHODS. Two independent experiments had similar results. B, Spectrophotomeric assays for the activity of Pel and Peh. Total activity was investigated. Data are expressed as the mean of Pel or Peh specific activity $\left(\mathrm{U} / \mathrm{OD}_{660}\right)$ from at least three independent experiments. 
lated probably at the posttranscriptional or posttranslational levels or both by the control of ClpXP protease. Here we have shown that in E. carotovora subsp. carotovora, the expression of $f l i A$ was reduced in the $\Delta c y t R$ mutant compared to that in the parental strain, while the expression of $f l h D$ (and $f l h C$ ) was slightly higher in the $\Delta c y t R$ mutant (Fig. 4). Thus, the CytR homologue in E. carotovora subsp. carotovora may affect the modulation of the $f l h D C / \mathrm{FlhDC}$ master regulator at the posttranscriptional or posttranslational levels or both via the control of one or more molecular chaperones or one or more proteases, such as ClpXP, or both. Consequently, such disordered relay at the expression of middle genes (including fliA) by the early class of FlhDC regulator might lead to the reduced expression of the late gene $f l i C$, though the present study cannot rule out the possibility that the CytR homologue in E. carotovora subsp. carotovora may control the expression of fliA or fliC or both without depending on the control of the FlhDC master regulator.

Taken together, synthesis of flagella and production of one or more virulence factors were shown to be closely regulated by the CytR homologue in E. carotovora subsp. carotovora, although Peh, which is considered to be one of the major virulence determinants, did not contribute to the virulence of $E$. $c a$ rotovora subsp. carotovora in our assays. Furthermore, our results showed that the loss of flagellar formation, which led to a loss of motility, a presumed secondary virulence factor, might contribute to the virulence of E. carotovora subsp. carotovora significantly in plants.

\section{MATERIALS AND METHODS}

\section{Bacterial strains, plasmids, and growth media.}

Bacterial strains and plasmids used in this study are described in Table 1. The strains of E. carotovora subsp. carotovora were grown in YP medium (1\% of peptone, $0.5 \%$ of yeast extract, $\mathrm{pH} 6.8)$ at $27^{\circ} \mathrm{C}$. E. coli strains were grown in LB (Luria-Bertani) medium ( $1 \%$ of tryptone, $0.5 \%$ of yeast extract, $0.5 \% \mathrm{NaCl}, \mathrm{pH} 7.0)$ at $37^{\circ} \mathrm{C}$. When required, antibiotics were added as follows: $30 \mu \mathrm{g}$ of nalidixic acid (Nal) per $\mathrm{ml} ; 50 \mu \mathrm{g}$ of kanamycin $(\mathrm{Km})$ per $\mathrm{ml} ; 30 \mu \mathrm{g}$ of chloramphenicol $(\mathrm{Cm})$ per $\mathrm{ml} ; 50 \mu \mathrm{g}$ of ampicillin (Amp) per $\mathrm{ml} ; 25$ $\mu \mathrm{g}$ of streptomycin (Stm) per ml; and $12.5 \mu \mathrm{g}$ of tetracycline (Tet) per ml. Optical density of the bacterial culture was measured by Bactomonitor BACT-500 at $660 \mathrm{~nm}$ (Intertech Inc., Tokyo).

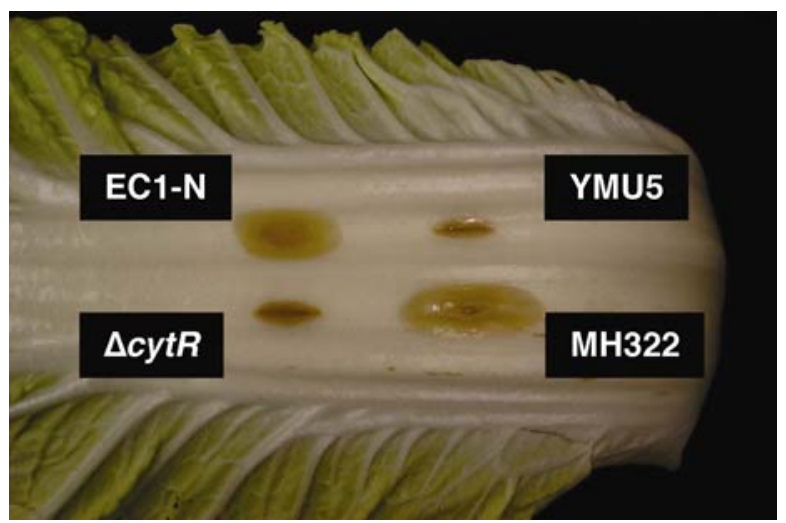

Fig. 6. Pathogenicity $24 \mathrm{~h}$ after inoculation with EC1-N, $\Delta c y t R$ mutant, YMU5, and MH322. Bacterial suspensions $(10 \mu \mathrm{l})$ adjusted to $\mathrm{OD}_{660}=1.0$ $\left(\approx 1.0 \times 10^{9} \mathrm{CFU} / \mathrm{ml}\right)$ were injected onto slits made with a sterile scalpel on a leaf of Chinese cabbage, which was then incubated in a moist chamber at $27^{\circ} \mathrm{C}$. Three independent experiments showed similar results.

\section{Recombinant DNA techniques.}

Preparation of total or plasmid DNA, PCR, restriction digestion, ligation, DNA electrophoresis, electroporation, and Southern blot hybridization were done as described by Ausubel and associates (1987) or Sambrook and associates (1989). Nucleotide sequence analysis was performed by DNA-Autosequencer (model 4000; Li-cor, Lincoln, NE, U.S.A.). Restriction and modifying enzymes were purchased from Nippon Gene (Tokyo) and New England Biolabs (Beverly, MA, U.S.A.).

\section{Tn5 mutagenesis.}

EC1-N, a spontaneous Nal-resistant mutant of E. carotovora subsp. carotovora strain EC1, was conjugated with a mobilizing strain of E. coli S17-1 that carried pSUP2021 harboring a transposon Tn5 (Simon et al. 1983). Transconjugants resistant to Nal and $\mathrm{Km}$ (Tn5 encoded) and to $\mathrm{Cm}$ and Amp (vector encoded) were first selected and then subcultured more than three times in YP medium without antibiotics. Nal- and Km-resistant colonies were tested for the loss of $\mathrm{Cm}$ and Amp resistance. Chinese cabbage leaves were inoculated with these $\mathrm{Nal}^{\mathrm{r}}, \mathrm{Km}^{\mathrm{r}}, \mathrm{Cm}^{\mathrm{s}}$, and $\mathrm{Amp}^{\mathrm{s}}$ colonies with toothpicks, and then incubated in a moist chamber at $27^{\circ} \mathrm{C}$ for $24 \mathrm{~h}$. The area of maceration formed by mutants was compared with that of the parental strain (EC1-N). The colonies that caused less maceration than that of the parental strain were chosen as the virulence-reduced mutants.

\section{DNA sequencing of Tn5-inserted sites.}

BamHI-digested fragments of total DNA extracted from the Tn5 mutants were ligated into the same site of pUC118, followed by electroporation into $E$. coli competent cells. Colonies resistant to both Amp and $\mathrm{Km}$ were picked up for preparation of plasmid DNA. The sequence of Tn5-inserted regions was determined using a specific sequence primer Tn5-leg (5'GGTTCCGTTCAGGACGCTAC-3') designed from the terminal sequence of $\operatorname{Tn} 5$.

\section{Nonpolar deletion mutant of the cytR homologue.}

Fragments containing either the N-terminal $(0.6 \mathrm{~kb})$ or $\mathrm{C}$ terminal $(1.2 \mathrm{~kb})$ region of the CytR homologue were amplified by PCR using primers cytR-BF (given earlier) and cytRFdR (5'-CCCTACGAAGCAGATATGTTGGTGAGCGCA-3') or primers cytR-RdF (5'-ATCTGCTTCGTAGGGTACAT CTTTCGGGGT-3') and cytR-BR (5'-CGGCAGGATCCAT GGTTTTGAAGGAGCCGC-3'), respectively (primers cytRFdR and cytR-RdF included a complementary 15-bp sequence at their $5^{\prime}$ ends). These two fragments were gel-purified using a QIAEX II gel extraction kit (Qiagen, Hilden, Germany) and then joined using the splicing by the overlap extension (SOE) technique (Horton et al. 1990; Lefebvre et al. 1995). A fragment was thus constructed with a 333-bp deletion in the ORF of $c y t R$ homologue in frame, which corresponds to amino acids 110 to 220 of the CytR homologue. After BamHI digestion of the fragment at the terminal ends, the digestion product was ligated into the same site of pKNG101 (Kaniga et al. 1991) to create $\mathrm{pDEL}-\mathrm{CytR}$. This plasmid was used to create a deletion in the cytR homologue in EC1-N by double homologous recombination using the sucrose selection marker (sacB) as described previously (Kaniga et al. 1991).

\section{Motility assays.}

The plate assay was initiated by stabbing single colonies, picked with sterile toothpicks from overnight cultures grown in YP medium, into a semisolid medium $(0.3 \%$ agar) (Wolfe and Berg 1989). The plate was incubated at $27^{\circ} \mathrm{C}$ and checked periodically. Motility of the bacteria in liquid culture was examined with a light microscope. 


\section{Electron microscopy.}

Bacterial cells were negatively stained using $1 \%$ phosphotungstic acid pH 7.0 (TAAB, Berkshire, England) on collodion-coated 200-mesh grids (Nisshin EM, Tokyo). Samples were visualized using a transmission electron microscope $(\mathrm{H}-$ 7500; Hitachi, Tokyo).

\section{RNA isolation.}

Total RNA was isolated using an ISOGEN RNA isolation kit (Nippon Gene, Tokyo), essentially according to instructions. To remove intact DNA completely, the resultant total RNA extract was treated with DNaseI for $1 \mathrm{~h}$ at $37^{\circ} \mathrm{C}$, followed by phenol/chloroform extraction and ethanol precipitation. The resultant total RNA was resuspended in RNase-free sterilized distilled water and then quantified by its optical density at $A_{260}$ with a spectrophotometer (Ultrospec 3000, Pharmacia Biotech, Cambridge, England).

\section{RT-PCR analysis.}

RT-PCR was performed using an mRNA-selective PCR kit (Ver. 1.1), essentially according to instructions (Takara, Shiga, Japan). One $\mu \mathrm{g}$ of total RNA was used as the template in a total reaction volume of $50 \mu \mathrm{l}$. The RT-reaction was performed at $42^{\circ} \mathrm{C}$ for $30 \mathrm{~min}$, followed by PCR $\left(90^{\circ} \mathrm{C}\right.$ for $1 \mathrm{~min}, 45^{\circ} \mathrm{C}$ for 1 min, and $72^{\circ} \mathrm{C}$ for $1 \mathrm{~min}$ ) for $20,25,33$, or 40 cycles. To verify the equivalency $(1 \mu \mathrm{g})$ of total RNA used here, 16S rDNA was chosen as the control. After adding one-fifth volume of loading buffer $(0.25 \%$ of bromophenol blue, $0.25 \%$ of xylene cyanol, $30 \%$ of glycerol, $5 \mathrm{mM}$ EDTA-NaOH $\mathrm{pH}$ 8.0) into each sample, $12 \mu \mathrm{l}$ of each sample was applied on a $1 \%$ agarose gel. Primers used in this experiment were as follows: flhD-F (5'ATGGGAAATATGGGTACCTC- $3^{\prime}$ ) and flhD-R (5'-TTATGCCCTTTTCTTAGGCAGGTTTT-3') for $f l h D$ expression analysis; fliA-F (5'-GAACTTGACGATCTGCTACAAGCTGGCGG-3') and fliA-R (5'-TCTTCACGCCACTCATCGTAAGAGAA-3') for fliA expression analysis; fliC-F (5'-ATGGCAGT-
AATTAATACTAA-3') and fliC-R3 (5'-AGCACTTGCAGAACCGTCCAGCAG-3') for fliC expression analysis; and 16SrDNA-F $\quad\left(5^{\prime}\right.$-AGAGGATGACCAGCCACACT-3') and 16SrDNA-R (5'-CGCATTTCACCGCTACACCT-3') for 16S rDNA expression analysis.

\section{Enzyme assays.}

Plate assays for activity of Pel, Peh, Cel, and Prt were done as described by Chatterjee and associates (1995) with slight modifications. The compositions were as follows: Pel activity assay medium (1\% of polyglacturonic acid (PGA), $1 \%$ of yeast extract, $50 \mu \mathrm{M} \mathrm{CaCl}_{2}, 50 \mathrm{mM}$ Tris- $\left.\mathrm{HCl} \mathrm{pH} 8.5\right)$, Peh activity assay medium (1\% of PGA, $1 \%$ of yeast extract, $2.5 \mathrm{mM}$ EDTA, $50 \mathrm{mM}$ sodium acetate $\mathrm{pH}$ 5.5), Cel activity assay medium $(0.1 \%$ of carboxymethyl cellulose, sodium phosphate $\mathrm{pH}$ 7.0), and Prt activity assay medium (3\% of gelatin and $1 \%$ of nutrient broth). The media were supplemented with $0.8 \%$ of agarose and $0.2 \%$ of sodium azide. Each petri plate $(100 \mathrm{~mm}$ diameter) contained $25 \mathrm{ml}$ of assay medium. Wells were made in the agarose medium with a No. 2 cork borer $(\phi 5 \mathrm{~mm})$, and the bottoms were sealed with $0.8 \%$ of molten agarose containing $0.2 \%$ of sodium azide.

To examine extracellular activity, culture supernatant was prepared by centrifuging $1 \mathrm{ml}$ of the culture at $15,000 \mathrm{rpm}$ for 2 min. For total activity, supernatant of the sonicated-cell extract was used. One $\mathrm{ml}$ of the culture was sonicated two times for $20 \mathrm{~s}$ (Ultrasonic Disrupter UD-200, Tomy, Tokyo) on ice and then centrifuged at $15,000 \mathrm{rpm}$ for $2 \mathrm{~min}$ to remove cell debris. The resultant supernatant was used. Either $30 \mu \mathrm{l}$ of the culture supernatant or the supernatant of the sonicated-cell extract was applied to each well. The plates were incubated for $20 \mathrm{~h}$ at $27^{\circ} \mathrm{C}$ for Pel, Peh, and Cel and for $48 \mathrm{~h}$ for Prt. The Pel and Peh plates were developed with $5 \mathrm{~N}$ of $\mathrm{H}_{2} \mathrm{SO}_{4}$. The Cel plates were stained with Congo red solution $(0.1 \%)$ for $10 \mathrm{~min}$ and then washed with $1 \mathrm{M} \mathrm{NaCl}$ several times. Haloes in the Prt plates became visible without any further treatment.

Table 1. Bacterial strains and plasmids

\begin{tabular}{|c|c|c|}
\hline Strain or plasmid & Relevant characteristics & Source or reference \\
\hline \multicolumn{3}{|c|}{ Erwinia carotovora subsp. carotovora } \\
\hline $\mathrm{EC} 1$ & Wild type & Laboratory collection \\
\hline EC1-N & Spontaneous $\mathrm{Nal}^{\mathrm{r}}$ mutant of $\mathrm{EC} 1, \mathrm{Nal}^{\mathrm{r}}$ & Laboratory collection \\
\hline YMU1 & EC1-N $f l h \mathrm{C}:: \mathrm{Tn} 5, \mathrm{Nal}^{\mathrm{r}}, \mathrm{Km}^{\mathrm{r}}$ & Matsumoto et al., in press \\
\hline YMU5 & EC1-N flhD::Tn5, $\mathrm{Nal}^{\mathrm{r}}, \mathrm{Km}^{\mathrm{r}}$ & Matsumoto et al., in press \\
\hline YMU18 & EC1-N cytR::Tn5, mutS::Tn5, $\mathrm{Nal}^{\mathrm{r}}, \mathrm{Km}^{\mathrm{r}}$ & This study \\
\hline$\Delta c y t R 1-4$ & $\mathrm{EC} 1-\mathrm{N} \Delta c y t R, \mathrm{Nal}^{\mathrm{r}}$ & This study \\
\hline MH322 & EC1-N peh::Tn3-gus, $\mathrm{Nal}^{\mathrm{r}}, \mathrm{Km}^{\mathrm{r}}$ & Laboratory collection \\
\hline \multicolumn{3}{|l|}{ Escherichia coli } \\
\hline S17-1 & 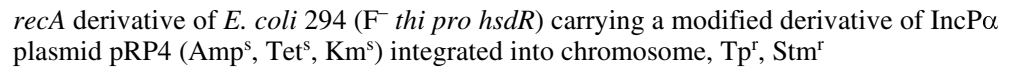 & Simon et al. 1983 \\
\hline DH10B & $\begin{array}{l}\mathrm{F}^{-} \text {mcrA } \Delta(m r r-h s d R M S-m c r B C) \phi 80 \mathrm{~d} l a c Z \Delta M 15 \Delta l a c X 74 \text { deoR recAl endA1 araD139 } \\
\Delta(\text { ara, leu }) 7697 \text { galU galK } \lambda^{-} \text {rpsL nup } G, \mathrm{Stm}^{\mathrm{r}}\end{array}$ & Invitrogen, Carisbad, CA, U.S.A. \\
\hline CC118 & $\triangle($ ara, leu $)$ araD $\triangle$ lacX74 galE galK phoA20 thi-1 rpsE rpoB argE $(\mathrm{am}) r e c A 1, \mathrm{Sp}^{\mathrm{r}}$ & Herrero et al. 1990 \\
\hline 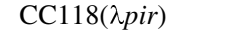 & CC118 lysogenized with $\lambda$ pir phage, $\mathrm{Sp}^{\mathrm{r}}$ & Herrero et al. 1990 \\
\hline HB101 & $\mathrm{F}^{-}$hsdS $\left(\mathrm{r}_{\mathrm{B}}^{-} \mathrm{m}_{\mathrm{B}}^{-}\right)$thi pro leu lacY ara xyl supE recA13, $\mathrm{Stm}^{\mathrm{r}}$ & Sambrook et al. 1989 \\
\hline \multicolumn{3}{|c|}{ 2. } \\
\hline pSUP2021 & Mobilizable plasmid carrying genes for $\mathrm{Tn} 5$ transposition, $\mathrm{Amp}^{\mathrm{r}}, \mathrm{Cm}^{\mathrm{r}}, \mathrm{Km}^{\mathrm{r}}$ & Simon et al. 1983 \\
\hline pUC118 & Cloning vector, $\mathrm{Amp}^{\mathrm{r}}$ & Takara, Tokyo \\
\hline pKNG101 & R6K origin $s a c B$ marker-exchange vector, $\mathrm{mob}^{+}, \mathrm{Stm}^{\mathrm{r}}$ & Kaniga et al. 1991 \\
\hline pRK2013 & Helper plasmid carrying genes for conjugation, $\mathrm{Km}^{\mathrm{r}}$ & Figurski and Helinski 1979 \\
\hline pYMU18-1 & $\begin{array}{l}\text { 4.3-kb Bam HI fragment of Tn } 5 \text { flanking one side of a disrupted region of YMU18 } \\
\text { cloned into the same site of pUC118 }\end{array}$ & This study \\
\hline pYMU18-2 & $\begin{array}{l}>10-\mathrm{kb} \text { Bam HI fragment of Tn } 5 \text { flanking one side of another disrupted region of } \\
\text { YMU18 cloned into the same site of pUC118 }\end{array}$ & This study \\
\hline $\mathrm{pS} 3-3$ & $\begin{array}{l}\text { 0.6-kb SalI fragment containing } 5^{\prime} \text { region of ORF of the } c y t R \text { homologue cloned into } \\
\text { the same site of pUC118 }\end{array}$ & This study \\
\hline pS3-21 & $\begin{array}{l}\text { 0.9-kb SalI fragment containing } 3^{\prime} \text { region of ORF of the cytR homologue cloned into } \\
\text { the same site of pUC118 }\end{array}$ & This study \\
\hline pDEL-CytR & $\begin{array}{l}\text { 1.8-kb PCR product containing ORF of the } c y t R \text { homologue deleted in frame, processed } \\
\text { with BamHI, cloned into the same site of pKNG101 }\end{array}$ & This study \\
\hline
\end{tabular}


Spectrophotomeric assay of Pel activity was done essentially as described by Zink and associates (1985). A $10 \mu \mathrm{l}$ of sample solution was added to $990 \mu \mathrm{l}$ of the reaction buffer $(0.05 \%$ PGA, 0.1 M Tris- $\mathrm{HCl} \mathrm{pH} 8.5,0.1 \mathrm{mM} \mathrm{CaCl}_{2}$, prewarmed to $30^{\circ} \mathrm{C}$ ). After a thorough mixing of the solution, the increase in optical density at $230 \mathrm{~nm}$ was measured every minute (Ultrospec 3000, Pharmacia Biotech, Cambridge, England). One unit of Pel activity was equivalent to an increase of $1 \times 10^{-3}$ optical density at $230 \mathrm{~nm}$ in $1 \mathrm{~min}$. Spectrophotomeric assay of Peh activity was done as described by Collmer et al. (1982). One unit of Peh activity corresponds to the amount of enzyme that produced $0.1 \mu \mathrm{mol}$ of glucose equivalent per minute at $30^{\circ} \mathrm{C}$.

\section{Pathogenicity tests.}

A few millimeters of slits made with a sterile scalpel on a leaf of Chinese cabbage were inoculated with $10 \mu \mathrm{l}$ of bacterial suspensions adjusted to $\mathrm{OD}_{660}=1.0\left(\approx 1.0 \times 10^{9} \mathrm{CFU} / \mathrm{ml}\right)$ of overnight cultures grown in YP medium. It was incubated in a moist chamber at $27^{\circ} \mathrm{C}$, and the appearance of the symptom was observed periodically.

\section{ACKNOWLEDGMENTS}

We thank B. E. Hazen for carefully revising the manuscript. This research was supported in part by Grant-in-Aid (No. 12052210) and by a grant from the Ministry of Education, Culture, Sports, Science, and Technology of Japan (No. 13073).

\section{LITERATURE CITED}

Aizawa, S.-I. 2000. Flagella. Pages 380-389 in: Encyclopedia of Microbiology. Vol. 2. J. Lederberg, ed. Academic Press, New York.

Aizawa, S.-I. 2001. Bacterial flagella and type III secretion systems. FEMS (Fed. Eur. Microbiol. Soc.) Microbiol. Lett. 202:157-164.

Aldridge, P., and Hughes, K. T. 2002. Regulation of flagellar assembly. Curr. Opin. Microbiol. 5:160-165.

Allen, C., Gay, J., and Simon-Buela, L. 1997. A regulatory locus, pehSR, controls polygalacturonase production and other virulence control system. J. Bacteriol. 175:3468-3479.

Andersson, R. A., Palva, E. T., and Pirhonen, M. 1999. The response regulator ExpM is essential for the virulence of Erwinia carotovora subsp. carotovora and acts negatively on the sigma factor RpoS $\left(\sigma^{\mathrm{s}}\right)$. Mol. Plant-Microbe Interact. 12:575-584.

Ausubel, F. M., Brent, R., Kingston, R. E., Moore, D. D., Seidman, J. G., Smith, J. A., and Struhl, K. 1987. Current Protocols in Molecular Biology. John Wiley and Sons, New York.

Barras, F., Van Gijsegem, F., and Chatterjee, A. K. 1994. Extracellular enzymes and pathogenesis of soft-rot Erwinia. Annu. Rev. Phytopathol. 32:201-234.

Bauer, D. W., Bogdanove, A. J., Beer, S. V., and Collmer, A. 1994. Erwinia chrysanthemi hrp genes and their involvement in soft rot pathogenesis and elicitation of the hypersensitive response. Mol. PlantMicrobe Interact. 7:573-581.

Brumbley, S. M., and Denny, T. P. 1990. Cloning of wild-type Pseudomonas solanacearum phcA, a gene that when mutated alters expression of multiple traits that contribute to virulence. J. Bacteriol. 172:5677-5685.

Castillo, A., and Reverchon, S. 1997. Characterization of the pecT control region from Erwinia chrysanthemi 3937. J. Bacteriol. 179:4909-4918.

Chatterjee, A., Cui, Y., Liu, Y., Dumenyo, C. K., and Chatterjee, A. K. 1995. Inactivation of $r s m A$ leads to overproduction of extracellular pectinases, cellulases, and proteases in Erwinia carotovora subsp. carotovora in the absence of the starvation/cell density sensing signal, $N$ (3-oxohexanoyl)-L-homoserine lactone. Appl. Environ. Microbiol. 61:1959-1967.

Chesnokova, O., Coutinho, J. B., Khan, I. H., Mikhail, M. S., and Kado, C. I. 1997. Characterization of flagella genes of Agrobacterium tumefaciens, and the effect of a bald strain on virulence. Mol. Microbiol. 23:579-590.

Chilcott, G. S., and Hughes, K. T. 2000. Coupling of flagellar gene expression to flagellar assembly in Salmonella enterica serovar Typhimurium and Escherichia coli. Microbiol. Mol. Biol. Rev. 64:694-708.

Collmer, A., and Keen, N. T. 1986. The role of pectic enzymes in plant pathogenesis. Annu. Rev. Phytopathol. 24:383-409.

Collmer, A., Whalen, C. H., Beer, S. V., and Bateman, D. F. 1982. An exo-poly- $\alpha$-D-galacturonosidase implicated in the regulation of extracellular pectate lyase production in Erwinia chrysanthemi. J. Bacteriol. 149:626-634.

Condemine, G., Castillo, A., Passeri, F., and Enard, C. 1999. The PecT repressor coregulates synthesis of exopolysaccharides and virulence factors in Erwinia chrysanthemi. Mol. Plant-Microbe Interact. 12:4552.

Dai, K., Xu, Y., and Lutkenhaus, J. 1993. Cloning and characterization of ftsN, an essential cell division gene in Escherichia coli, isolated as a multicopy suppressor of ftsA12(Ts). J. Bacteriol. 175:3790-3797.

Enard, C., Diolez, A., and Expert, D. 1988. Systemic virulence of Erwinia chrysanthemi 3937 requires a functional iron assimilation system. J. Bacteriol. 170:2419-2426.

Figurski, D. H., and Helinski, D. R. 1979. Replication of an origincontaining derivative of plasmid RK2 dependent on a plasmid function provided in trans. Proc. Natl. Acad. Sci. U.S.A. 76:1648-1652.

Gunasekera, A., Ebright, Y. W., and Ebright, R. H. 1992. DNA sequence determinants for binding of the Escherichia coli catabolite gene activator protein. J. Mol. Chem. 267:14713-14720.

Hammer-Jespersen, K. 1983. Nucleoside catabolism. Pages 203-258 in Metabolism of Nucleotides, Nucleosides and Nucleobases in Microorganisms. A. Munch-Petersen, ed. Academic Press, London.

Harris, S. J., Shih, Y.-L., Bentley, S. D., and Salmond, G. P. C. 1998. The hexA gene of Erwinia carotovora encodes a LysR homologue and regulates motility and the expression of multiple virulence determinants. Mol. Microbiol. 28:705-717.

Hassouni, M. E., Chambost, J. P., Expert, D., Van Gijsegem, F., and Barras, F. 1999. The minimal gene set member $m s r A$, encoding peptide methionine sulfoxide reductase, is a virulence determinant of the plant pathogen Erwinia chrysanthemi. Proc. Natl. Acad. Sci. U.S.A. 96:887892.

Haugo, A. J., and Watnick, P. I. 2002. Vibrio cholerae CytR is a repressor of biofilm development. Mol. Microbiol. 45:471-483.

Herrero, M., de Lorenzo, V., and Timmis, K. N. 1990. Transposon vectors containing non-antibiotic resistance selection markers for cloning and stable chromosomal insertion of foreign genes in gram-negative bacteria. J. Bacteriol. 172:6557-6567.

Horton, R. M., Cai, Z. L., Ho, S. N., and Pease, L. R. 1990. Gene splicing by overlap extension: Tailor-made genes using the polymerase chain reaction. Biotechniques 8:528-535.

Hueck, C. J. 1998. Type III protein secretion systems in the bacterial pathogens of animals and plants. Microbiol. Mol. Biol. Rev. 62:379433.

Hugouvieux-Cotte-Pattat, N., Condemine, G., Nasser, W., and Reverchon, S. 1996. Regulation of pectinolysis in Erwinia chrysanthemi. Annu. Rev. Microbiol. 50:213-257.

Josenhans, C., and Suerbaum, S. 2002. The role of motility as a virulence factor in bacteria. Int. J. Med. Microbiol. 291:605-614.

Kallipolitis, B. H., and Valentin-Hansen, P. 1998. Transcription of $r p o H$, encoding the Escherichia coli heat-shock regulator $\sigma^{32}$, is negatively controlled by the cAMP-CRP/CytR nucleoprotein complex. Mol. Microbiol. 29:1091-1099.

Kaniga, K., Delor, I., and Cornelis, G. R. 1991. A wide-host-range suicide vector for improving reverse genetics in Gram-negative bacteria: Inactivation of the blaA gene of Yersinia enterocolitica. Gene 109:137-141.

Keen, N. T., Tamaki, S., Kobayashi, D., and Trollinger, D. 1988. Improved broad-host-range plasmids for DNA cloning in Gram-negative bacteria. Gene 70:191-197.

Kotoujansky, A. 1987. Molecular genetics of pathogenesis by soft-rot Erwinias. Annu. Rev. Phytopathol. 25:405-430.

Kutsukake, K., Ohya, Y., and Iino, T. 1990. Transcriptional analysis of the flagellar regulon of Salmonella typhimurium. J. Bacteriol. 172:741-747.

Lefebvre, B., Formstecher, P., and Lefebvre, P. 1995. Improvement of the gene splicing overlap (SOE) method. Biotechniques 19:186-188.

Liu, X., and Matsumura, P. 1994. The FlhD/FlhC complex, a transcriptional activator of the Escherichia coli flagellar class II operons. J. Bacteriol. 176:7345-7351.

Lopez-Solanilla, E., Garcia-Olmedo, F., and Rodriguez-Palenzuela, P. 1998. Inactivation of the sapA to sapF locus of Erwinia chrysanthemi reveals common features in plant and bacterial pathogenesis. Plant Cell 10:917-924.

Matsumoto, H., Umehara, M., Muroi, H., Yoshitake, Y., and Tsuyumu S. A homologue of FlhDC, a master regulator for flagellum synthesis, is required for pathogenicity in Erwinia carotovora subsp. carotovora. J. Gen. Plant Pathol. In press.

Modrich, P., and Lahue, R. 1996. Mismatch repair in replication fidelity, genetic recombination, and cancer biology. Annu. Rev. Biochem. 65:101-133.

Mukherjee, A., Cui, Y., Liu, Y., Dumenyo, C. K., and Chatterjee, A. K. 
1996. Global regulation in Erwinia species by Erwinia carotovora rsmA, a homologue of Escherichia coli csrA: repression of secondary metabolites, pathogenicity and hypersensitive reaction. Microbiology 142:427-434.

Mulholland, V., Hinton, J. C. D., Sidebotham, J., Toth, I. K., Hyman, L. J., Perombelon, M. C. M., Reeves, P. J., and Salmond, G. P. C. 1993. A pleiotropic reduced virulence $\left(\mathrm{Rvi}^{-}\right)$mutant of Erwinia carotovora subspecies atroseptica is defective in flagella assembly proteins that are conserved in plant and animal bacterial pathogens. Mol. Microbiol. 9:343-356.

Nasser, W., Faelen, M., Hugouvieux-Cotte-Pattat, N., and Reverchon, S. 2001. Role of the nucleoid-associated protein H-NS in the synthesis of virulence factors in the phytopathogenic bacterium Erwinia chrysanthemi. Mol. Plant-Microbe Interact. 14:10-20.

Norregaard-Madsen, M., Mygind, B., Pedersen, R., Valentin-Hansen, P., and Sogaard-Anderson, L. 1994. The gene encoding the periplasmic cyclophilin homologue, PPlase A, in Escherichia coli, is expressed from four promoters, three of which are activated by the cAMP-CRP complex and negatively regulated by $\mathrm{CytR}$ repressor. Mol. Microbiol. 14:989-997.

Nurse, P., DiGate, R. J., Zavitz, K. H., and Marians, K. J. 1990. Molecular cloning and DNA sequence analysis of Escherichia coli priA, the gene encoding the primosomal protein replication factor Y. Proc. Natl. Acad. Sci. U.S.A. 87:4615-4619.

Ottemann, K. M., and Miller, J. F. 1997. Roles for motility in bacterialhost interactions. Mol. Microbiol. 24:1109-1117.

Pedersen, H., Sogaard-Andersen, L., Holst, B., Gerlach, P., Bremer, E., and Valentin-Hansen, P. 1992. cAMP-CRP activator complex and the CytR repressor protein bind co-operatively to the $c y t R P$ promoter in Escherichia coli and CytR antagonizes the cAMP-CRP-induced DNA bend. J. Mol. Biol. 227:396-406.

Perombelon, M. C. M., and Kelman, A. 1980. Ecology of the soft rot erwinias. Annu. Rev. Phytopathol. 18:361-387.

Pirhonen, M., Saarilahti, H., Karlson, M.-B., and Palva, E. T. 1991. Identification of pathogenicity determinants of Erwinia carotovora subspecies carotovora by transposon mutagenesis. Mol. Plant-Microbe Interact. 4:276-283.

Pruss, B. M., and Matsumura, P. 1996. A regulator of the flagellar regulon of Escherichia coli, flhD, also affects cell division. J. Bacteriol. 178:668-674.

Rasmussen, P. B., Sogaard-Andersen, L., and Valentin-Hansen, P. 1993. Identification of the nucleotide sequence recognized by the cAMP$\mathrm{CRP}$ dependent $\mathrm{CytR}$ repressor protein in the deoP 2 promoter in $E$. coli. Nucleic Acids Res. 21:879-885.

Robert-Baudouy, J., Nasser, W., Condemine, G., Reverchon, S., Shevchik, V. E., and Hugouvieux-Cotte-Pattat, N. 2001. Pectic enzymes of Erwinia chrysanthemi, regulation and role in pathogenesis. Pages 221-268 in: Advances in Molecular Genetics of Plant-Microbe
Interactions Vol. 5. G. Stacey and N. T. Keen, eds. The American Phytopathological Society, St. Paul, MN, U.S.A.

Sambrook, J., Fritsch, E. F., and Maniatis, T. A. 1989. Molecular Cloning: A Laboratory Manual, 2nd ed. Cold Spring Harbor Laboratory Press, Cold Spring Harbor, NY, U.S.A.

Schoonejans, E., Expert, D., and Toussaint, A. 1987. Characterization and virulence properties of Erwinia chrysanthemi lipopolysaccharidedefective, phiEC2-resistant mutants. J. Bacteriol. 169:4011-4017.

Shi, W., Zhou, Y., Wild, J., Adler, J., and Gross, C. A. 1992. DnaK, DnaJ, and GrpE are required for flagellum synthesis in Escherichia coli. J. Bacteriol. 174:6256-6263.

Shih, Y.-L., Harris, S. J., Borner, G., Rivet, M. M., and Salmond, G. P. C. 1999. The hexY genes of Erwinina carotovora ssp. carotovora and ssp. atroseptica encode novel proteins that regulate virulence and motility co-ordinately. Environ. Microbiol. 1:535-547.

Simon, R., Priefer, U. B., and Puhler, A. 1983. A broad host range mobilization system for in vivo genetic engineering: Transposon mutagenesis in Gram-negative bacteria. Bio/Technology 1:784-790.

Tans-Kersten, J., Huang, H., and Allen, C. 2001. Ralstonia solanacearum needs motility for invasive virulence on tomato. J. Bacteriol. 183:3597-3605.

Thomsen, L. E., Pedersen, M., Norregaard-Madsen, M., Valentin-Hansen, P., and Kallipolitis, B. H. 1999. Protein-ligand interaction: Grafting of the uridine-specific determinants from the CytR regulator of Salmonella typhimurium to Escherichia coli cytR. J. Mol. Biol. 288:165-175.

Tomoyasu, T., Ohkishi, T., Ukyo, Y., Tokumitsu, A., Takaya, A., Suzuki, M., Sekiya, K., Matsui, H., Kutsukake, K., and Yamamoto, T. 2002. The ClpXP ATP-dependent protease regulates flagellum synthesis in Salmonella enterica serovar Typhimurium. J. Bacteriol. 184:645-653.

Valentin-Hansen, P., Larsen, J. E. L., Hojrup, P., Short, S. A., and Barbier C. S. 1986. Nucleotide sequence of the CytR regulatory gene of E. coli K-12. Nucleic Acids Res. 14:2215-2228.

Valentin-Hansen, P., Sogaard-Andersen, L., and Pedersen, H. 1996. A flexible partnership: the CytR anti-activator and the cAMP-CRP activator protein, comrades in transcription control. Mol. Microbiol. 20:461-466.

Wei, X., and Bauer, W. D. 1999. Tn5-induced and spontaneous switching of Sinorhizobium meliloti to faster-swarming behavior. Appl. Environ. Microbiol. J. Bacteriol. 65:1228-1235.

Wolfe, A. J., and Berg, H. C. 1989. Migration of bacteria in semisolid agar. Proc. Natl. Acad. Sci. U.S.A. 86:6973-6977.

Young, G. M., Schmiel, D. H., and Miller, V. L. 1999. A new pathway for the secretion of virulence factors by bacteria: The flagellar export apparatus functions as a protein-secretion system. Proc. Natl. Acad. Sci. U.S.A. 96:6456-6461.

Zink, R. T., Engwall, J. K., McEvoy, J. L., and Chatterjee, A. K. 1985. $r e c A$ is required in the induction of pectin lyase and carotovoricin in Erwinia carotovora subsp. carotovora. J. Bacteriol. 164:390-396. 